\title{
Effect of Different Potting Media on Nutrient Composition of Soil and Leaves of Litchi Air Layers
}

\author{
Sarita*, Parshant Bakshi, Kiran Kour, Unique Mehla, Bhawana, Sunny Sharma, \\ Amit Jasrotia and Bharat Bhushan
}

Sher-e-Kashmir University of agricultural Sciences and technology, Jammu, India

*Corresponding author

\section{A B S T R A C T}

\section{Keywords}

Litchi air layers, PGPR

Article Info

Accepted:

10 September 2019

Available Online:

10 October 2019
During 2018-19, effects of different organic nutrient sources were tested on litchi cv. Dehradun in terms of nutrient composition of soil and leaves at Advanced Centre for Horticulture Research, Udheywalla, Sher-e-Kashmir University of Agricultural Sciences and Technology of Jammu. This experiment demonstrated significant differences in the nutrient element composition of soil and leaves of litchi air layers. The maximum NPK content (294.76 kg/ha, $31.43 \mathrm{~kg} / \mathrm{ha}$ and $177.42 \mathrm{~kg} / \mathrm{ha}$, respectively) of soil was recorded in media containing litchi orchard soil along with FYM and rhizobacteria whereas, the minimum NPK content $(245.94 \mathrm{~kg} / \mathrm{ha}, 8.80 \mathrm{~kg} / \mathrm{ha}$ and $100.39 \mathrm{~kg} / \mathrm{ha}$, respectively) of soil was recorded in control. The NPK content of litchi leaves $(1.46 \%, 0.24 \%$ and $2.16 \%$, respectively) was found to be significantly higher in treatment containing litchi orchard soil in combination with FYM and rhizobacteria, whereas, the minimum NPK content of leaves $(1.08 \%, 0.14 \%$ and $1.45 \%$, respectively) was recorded in control. The results of this study suggest that rhizobacteria has the potential to increase the soil fertility as well as nutrient composition of litchi leaves which will ultimately enhance the plant growth and development as well as yield.

\section{Introduction}

Many agricultural soils of the world are deficient in one or more of the essential nutrients needed to support healthy plants. Addition of amendments is essential for a proper nutrient supply and maximum yields. The use of chemical fertilizers to enhance soil fertility and crop productivity has often negatively affected the complex system of biogeochemical cycles. Therefore, interest has grown in environmentally sustainable and organic agricultural practices (Esitken et al., 2005). The beneficial effects of organic nutrients on soil fertility have been repeatedly shown, yet there are no guidelines for their management. Organic materials are not magic; many of their functions with respect to soil fertility are known. Organic materials influence nutrient availability (i) by adding nutrients (ii) through mineralizationimmobilization patterns, (iii) as an energy source for microbial activities, (iv) as precursors to soil organic matter (SOM), and 
(v) by reducing $\mathrm{P}$ sorption of the soil (Palm et al., 1997). The challenge is to enhance soil fertility with organic sources to optimize nutrient availability to plants. One potential way to decrease negative environmental impacts resulting from inefficient use of chemical fertilizers is inoculation with plant growth promoting rhizobacteria (PGPR). These bacteria exert beneficial effects on plant growth and development and therefore, may be used as biofertilizers for agriculture (Adesemoye et al., 2009). Capabilities of PGPR range from enhancing yields of organic systems to pollution control. A principal problem of organic farming is the low nutrient status of most organic fertilizers (Mengel and Kirkby, 1987). Nutrient content of organic fertilizers varies widely depending on the source and moisture content (Yildrim et al., 2001). This problem is further compounded by the difficulties in assessing the value of organic fertilizers through direct analysis of total quantities of plant nutrients. Thus, field experiments are needed to determine the nutrient availability and efficiency of most organic fertilizers. This is the result of the slow and variable release rates of nutrients during decomposition of organic materials (Hsieh and Hsieh, 1990). Biofertilizers with PGPR can be used to increase soil productivity and plant growth in sustainable agriculture through increasing mineral and organic fertilizer use efficiency (Adesemoye et al., 2009). Therefore, a study was conducted to investigate the effects of organic manures and biofertilizer on nutrient content of soil and leaves of litchi air layers.

\section{Materials and Methods}

The present investigation was carried out at the Advanced Centre for Horticulture Research, Udheywalla, Sher-e-Kashmir University of Agricultural Sciences and Technology of Jammu during 2018-19. Different types of potting media such as soil, litchi orchard soil, FYM, sawdust, vermicompost, vermiculite, perlite, neem cake, plant growth promoting rhizobacteria (Azotobacter) and cocopeat were used in different combinations after thorough mixing of the ingredients at the experimental farm. The experiment was laid out on randomized block design with twelve treatments and three replications with twenty plants in each replication. The prepared mixtures of the various growing media were field in plastic polybags $\left(30 \times 20 \times 15 \mathrm{~cm}^{3}\right)$ and kept in open field conditions. Half of the bags were filled with mixtures before planting and remaining half portion was filled after putting the litchi air-layers cv. Dehradun in middle portion and compress from the side for complete contact with mixtures and water immediately with watering can. Light irrigation was given 3-4 times daily to maintain the proper humidity in open conditions. Observations on nutrient composition of soil as well as of leaves of litchi air layers were recorded for each treatment after six months of transplanting of air layers in potting media. The soilsamples were collected after six months and then air dried.T he leaf samples were collected from $3^{\text {rd }}$ pair of leaflets after six months and then oven dried and grinded. The available nitrogen was determined by Kjeldahl method, available phosphorous by Olsen method (Olsen et al., 1954), available potassium by Flame Photometer method (Table 1).

\section{Results and Discussion}

\section{Nutrient content of leaf}

Nitrogen content of leaves was found to be significantly higher $(1.46 \%)$ in treatment containing litchi orchard soil in combination with rhizobacteria, whereas, the minimum nitrogen content of leaves $(1.08 \%)$ was recorded in control. This might be due to that larger root system might have further assisted in efficient moisture and nutrient absorption 
and hence, higher $\mathrm{N}$ and $\mathrm{K}$ content in leaf was recorded in growing media comprising litchi orchard soil in combination with rhizobacteria and FYM. Leaf P concentration did not vary significantly due to treatments. However, saplings grown in litchi orchard soil alongwith rhizobacteria and FYM recorded higher leaf $\mathrm{P}$ compared to other treatments. He et al., (2003) observed in maize that arbuscular mycorrhiza readily absorbed and translocated ammonium with below ground hyphal network connection with neighbouring root which transfer $\mathrm{N}$ from plant to plant. Sharma et al., (2016) reported that plant growth promoting rhizobacteria live in close association with plant roots and have significant potential to improve nutrient use efficiency with plethora of mechanisms with extensive root hyphae for nutrient absorption, release of phytohormone for stimulation of root growth and alteration of plant metabolism for higher nutrient acquisition. Rhizobacteria inoculants increased $\mathrm{N}$ and $\mathrm{P}$ accumulation in plant tissue in comparison to control plants, suggesting that the mycorrhizal and bacterial plants were using $\mathrm{P}$ sources available due to activity of plant growth promoting rhizobacteria (Sharma et al., 2016). The findings are also in agreement with those of Rai et al., (2002) and Kumar et al., (2014) in litchi (Table 2).

\section{Nutrient content of soil}

The maximum NPK content of soil was recorded in media containing litchi orchard soil along with rhizobacteria. According to Vejan et al., (2016) sufficient densities of rhizobacteria in biofertilizer provide a beneficial role in creating a proper rhizosphere for plant growth and converting nutritionally important elements through biological process, for example increasing the availability of $\mathrm{N}, \mathrm{P}, \mathrm{K}$, as well as inhibiting pathogen growth. The high availability of N, P and $\mathrm{K}$ could enhance soil fertility, improve antagonistic isolates, bio-control effects and extend microorganisms survival rates in soil. Our findings are supported by Burdman et al., (2000), Dey et al., (2004) in peanut, Lopez et al., (2005) in papaya and Ilyas et al., (2015) in kinnow.

Table.1 Different treatment combinations

\begin{tabular}{|c|l|}
\hline Notations & Treatment combinations \\
\hline $\mathbf{M}_{\mathbf{1}}$ & Soil + Sand + FYM (1:1:1) \\
\hline $\mathbf{M}_{\mathbf{2}}$ & Litchi orchard soil + Sand + FYM (1:1:1) \\
\hline $\mathbf{M}_{\mathbf{3}}$ & Litchi orchard soil + Sawdust + FYM (1:1:1) \\
\hline $\mathbf{M}_{\mathbf{4}}$ & Litchi orchard soil + Sawdust + Vermicompost (1:1:1) \\
\hline $\mathbf{M}_{\mathbf{5}}$ & $\begin{array}{l}\text { Soil + FYM (1:1) + Plant growth promoting rhizobacteria (PGPR) } \\
\text { @ 50g/kg }\end{array}$ \\
\hline $\mathbf{M}_{\mathbf{6}}$ & $\begin{array}{l}\text { Litchi orchard soil + FYM (1:1) + Plant growth promoting } \\
\text { rhizobacteria (PGPR) @ 50g/kg }\end{array}$ \\
\hline $\mathbf{M}_{\mathbf{7}}$ & Litchi orchard soil + Neem cake + FYM (1:1:1) \\
\hline $\mathbf{M}_{\mathbf{8}}$ & Litchi orchard soil + Perlite + FYM (1:1:1) \\
\hline $\mathbf{M}_{\mathbf{9}}$ & Litchi orchard soil+ Cocopeat + FYM (1:1:1) \\
\hline $\mathbf{M}_{10}$ & Litchi orchard soil + Vermiculite + FYM (1:1:1) \\
\hline $\mathbf{M}_{11}$ & Litchi orchard soil \\
\hline $\mathbf{M}_{\mathbf{1 2}}$ & Control (soil) \\
\hline
\end{tabular}


Table.2 Effect of different potting media on nutrient composition of leaves of air layered litchi plants cv.Dehradun

\begin{tabular}{|c|c|c|c|c|}
\hline \multicolumn{2}{|c|}{ Treatments } & \multirow{2}{*}{$\begin{array}{c}\text { Nitrogen } \\
(\%) \\
1.15\end{array}$} & \multirow{2}{*}{$\begin{array}{c}\text { Phosphorous } \\
(\%)\end{array}$} & \multirow{2}{*}{$\begin{array}{c}\text { Potassium } \\
(\%) \\
1.85\end{array}$} \\
\hline $\mathbf{M}_{1}$ : & $($ Soil + Sand + FYM $)$ & & & \\
\hline $\mathbf{M}_{2}$ : & $($ Litchi orchard soil + Sand + FYM) & 1.34 & 0.16 & 2.05 \\
\hline $\mathbf{M}_{3}$ : & (Litchi orchard soil + Sawdust + FYM) & 1.36 & 0.14 & 2.06 \\
\hline $\mathbf{M}_{4}$ : & (Litchi orchard soil + Sawdust + Vermicompost) & 1.35 & 0.15 & 2.06 \\
\hline $\mathbf{M}_{5}$ : & $($ Soil + Rhizobacteria + FYM $)$ & 1.37 & 0.16 & 2.16 \\
\hline $\mathbf{M}_{6}$ : & $($ Litchi orchard soil + Rhizobacteria + FYM) & 1.46 & 0.24 & 2.16 \\
\hline $\mathbf{M}_{7}:$ & (Litchi orchard soil + Neem cake + FYM) & 1.35 & 0.16 & 2.04 \\
\hline $\mathbf{M}_{8}$ : & (Litchi orchard soil + Perlite + FYM) & 1.36 & 0.15 & 2.03 \\
\hline $\mathbf{M}_{9}$ : & (Litchi orchard soil + Cocopeat + FYM) & 1.35 & 0.16 & 2.15 \\
\hline $\mathbf{M}_{10}:$ & (Litchi orchard soil + Vermiculite + FYM) & 1.35 & 0.15 & 2.14 \\
\hline $\mathbf{M}_{11}$ : & (Litchi orchard soil) & 1.35 & 0.15 & 2.04 \\
\hline \multirow[t]{3}{*}{$M_{12}:$} & (Control) & 1.08 & 0.14 & 1.45 \\
\hline & C.D. $(0.05)$ & 0.04 & N.S. & 0.06 \\
\hline & S.E $(+)$ & 0.01 & 0.00 & 0.02 \\
\hline
\end{tabular}

Table.3 Effect of different potting media on nutrient composition of soil of air layered litchi plants cv. Dehradun

\begin{tabular}{|l|l|c|c|c|}
\hline \multicolumn{2}{|c|}{ Treatments } & $\begin{array}{c}\text { Nitrogen } \\
\text { (kg/ha) }\end{array}$ & $\begin{array}{c}\text { Phosphorous } \\
(\mathbf{k g} / \mathbf{h a})\end{array}$ & $\begin{array}{c}\text { Potassium } \\
\text { (kg/ha) }\end{array}$ \\
\hline $\mathbf{M}_{\mathbf{1}}:$ & (Soil + Sand + FYM) & 250.06 & 9.20 & 103.03 \\
\hline $\mathbf{M}_{\mathbf{2}}:$ & (Litchi orchard soil + Sand + FYM) & 262.00 & 16.25 & 163.66 \\
\hline $\mathbf{M}_{\mathbf{3}}:$ & (Litchi orchard soil + Sawdust + FYM) & 270.86 & 16.42 & 163.43 \\
\hline $\mathbf{M}_{\mathbf{4}}:$ & (Litchi orchard soil + Sawdust + Vermicompost) & 280.03 & 17.37 & 171.58 \\
\hline $\mathbf{M}_{\mathbf{5}}:$ & (Soil + Rhizobacteria + FYM) & 291.94 & 27.03 & 174.48 \\
\hline $\mathbf{M}_{\mathbf{6}}:$ & (Litchi orchard soil + Rhizobacteria + FYM) & 294.76 & 31.43 & 177.42 \\
\hline $\mathbf{M}_{\mathbf{7}}:$ & (Litchi orchard soil + Neem cake + FYM) & 271.86 & 16.46 & 168.52 \\
\hline $\mathbf{M}_{\mathbf{8}}:$ & (Litchi orchard soil + Perlite + FYM) & 280.04 & 18.37 & 171.51 \\
\hline $\mathbf{M}_{\mathbf{9}}:$ & (Litchi orchard soil + Cocopeat + FYM) & 278.99 & 19.44 & 171.35 \\
\hline $\mathbf{M}_{\mathbf{1 0}}:$ & (Litchi orchard soil + Vermiculite + FYM) & 282.96 & 18.36 & 173.21 \\
\hline $\mathbf{M}_{\mathbf{1 1}}:$ & (Litchi orchard soil) & 261.90 & 16.22 & 163.13 \\
\hline $\mathbf{M}_{\mathbf{1 2}}:$ & (Control) & 245.94 & 8.80 & 100.39 \\
\hline & C.D. $(0.05)$ & 8.21 & 0.84 & 3.02 \\
\hline & S.E $( \pm)$ & 2.80 & 0.29 & 1.02 \\
\hline
\end{tabular}

In conclusion, efficient plant nutrition management should ensure both enhanced and sustainable agricultural production and safeguard the environment. The present study 
suggests that the use of plant growth promoting rhizobacteria along with FYM and litchi orchard soil has the potential to increase the soil fertility as well as leaf nutrient composition in litchi plants under organic growing conditions.

\section{References}

Burdman, S., Jurkevitch, E. and Okon, Y. 2000. Recent advances in the use of plant growth promoting rhizobacteria in agriculture. Microbial Interactions in Agriculture and Forestry, 2: 229-250.

Dey, R., Pal, K. K., Bhatt, D. M. and Chauhan, S. M. 2004. Growth promotion and yield enhancement of peanut (Arachis hypogaea L.) by application of plant growth promoting rhizobacteria. Microbiological

Research, 159: 371-394.

He, Z. L., Calvert, D. V., Alva, A. K., Banks, D. J. and Li, Y. C. 2003. Thresholds of leaf nitrogen for optimum fruit production and quality in grapefruit. Soil Science Society of America Journal, 67: 583-588.

Ilyas, K. M., Sharma, A., Rani, S., Wali, V. K. and Bakshi, P. 2015. Effect of propagation media and black polybags on growth and survival of budded kinnow plants. The Bioscan, 10(2): 579584.

Kumar, A., Pandey, S. D., Rai, R. R. and Nath, V. 2014. Evaluation of alternate potting media mixtures for raising quality planting material of litchi in polybags. The Bioscan, 9(1): 381-384.

Lopez, M. H., Ferrera, C. R., Farias, L. J., Aguilar, E. S., Bello, M. D. R. F. and Lopez, A. J. G. 2005. Arbuscular mycorrhizae, Bacillus and substrate enriched with vermicompost on the development of papaya plants. Terra, 23(4): 523-531.

Olsen, S. R., Cole, C. W., Watanabe, P. S. and Dean, L. A. 1954. Estimation of average phosphorus in soil by extraction with $\mathrm{NaHCO}_{3}$. United States Department of Agriculture Circular, 939: 19.

Rai, M., Dey, P., Gangopadhyay, K. K., Das, B., Nath, V., Reddy, N. N. and Singh, H. P. 2002. Influence of nitrogen, phosphorous and potassium on growth parameters, leaf nutrient composition and yield of litchi (Litchi chinensis). Indian Journal of Agricultural Sciences, 72(5): 267-70.

Vejan, P., Abdullah, R., Khadiran, T., Ismail, S. and Boyce, A. N. 2016. Role of plant growth promoting rhizobacteria in agricultural sustainability-a review. Molecules, 21(573): 1-17.

Adesemoye, A.O., Torbert, H.A. and Kloepper, J. W. 2009. Plant growthpromoting rhizobacteria allow reduced application rates of chemical fertilizers. Microbial Ecology, 58: 921-929.

Esitken, A., Ercisli, S., Karlidag, H. and Sahin, F. 2005. Potential use of plant growth promoting rhizobacteria (PGPR) in organic apricot production. International Conference on Environmentally Friendly Fruit Growing. Tartu, Estonia, 7-9 Sept. pp. 90-97.

Hsieh, S.C. and Hsieh, C. F. 1990.Theuseoforganic matter in crop production. Extension Bulletin No.315, Food and Fertilizer Technology Centre for the Asian and Pacific Region, Taipei.

Mengel, K. and E.A. Kirkby. 1987. In: Principles of plant nutrition. IPI, Bern, Switzerland.

Yildrim, E., Karlidag, H., Turan, M., Dursun, A. and Goktepe, F. 2011. Growth, nutrient uptake and yield promotion of Broccoli by plant growth promoting rhizobacteria with manure. HortScience, 46(6): 932-936. 
Palm, C. A., Myers, R. J.K. and Nandwa, S. M. 1997. Combined Use of Organic and Inorganic Nutrient Sources for Soil Fertility Maintenance and Replenishment. In: R. J. Buresh, P. A.
Sanchez, F. Calhoun, editors, Replenishing Soil Fertility in Africa, SSSA Spec. Publ. 51. SSSA and ASA, Madison, WI. pp. 193-217.

\section{How to cite this article:}

Sarita, Parshant Bakshi, Kiran Kour, Unique Mehla, Bhawana, Sunny Sharma, Amit Jasrotia and Bharat Bhushan. 2019. Effect of Different Potting Media on Nutrient Composition of Soil and Leaves of Litchi Air Layers. Int.J.Curr.Microbiol.App.Sci. 8(10): 928-933.

doi: https://doi.org/10.20546/ijcmas.2019.810.108 